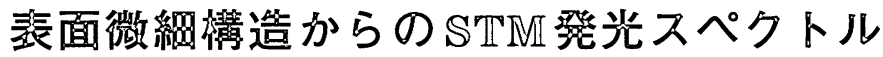

\author{
上原洋一・潮田資勝 \\ 東北大学電気通信研究所 $\quad$-990-77 仙台市青葉区片平 2-1-1
}

（1995年 1 月17日受理）

\section{STM Light Emission Spectroscopy of Surface Micro-Structures}

\author{
Yoichi UeHARA and Sukekatsu Ushioda \\ Research Institute of Electrical Communication \\ Tohoku University \\ 2-1-1, Katahira, Aoba-ku, Sendai 980-77
}

(Received January 17, 1995)

STM 発光についてこれまでの研究を簡単に概観したのち, 表面微細構造とSTM 発光スペクトル形状の相関 を研究することにより得られた最近の結果について解説する。

\section{1.はじめに}

1988年 IBMチューリッヒのグループは銀 $(\mathrm{Ag})$ を試料 として, STM (走査型トンネル電子顕微鏡)の電子トン ネルに伴う探針-試料近傍からの可視発光を初めて観測 したり。この発光はトンネル電子により励起された銀の ローカル・プラズモンからの発光であるが, GaAsのよ うな直接遷移型半導体を試料とした場合にはバンド間遷 移に伴う発光が報告されている2)。また，シリコンのよ うな間接遷移型で, しかもバンドギャップが赤外域にあ る半導体においてもSTM 可視発光が観測されている3)。 これらの実験結果はSTM発光が種々の発光機構で生じ ることを示し, その発光機構の研究は物理的にたいへん 興味深い。

また, STM からの発光は探針先端から試料の限られ た領域への電子 (もしくはホール) 注入に伴うものであ るから, STMの発光分析は試料表面の微視的領域の物 性（特に光物性）を探るための新しい手段として大いに 期待できる。

この解説では第 2 章でこれまでの STM 発光全般の研 究を概観したあと, 第3 章でわれわれが最近得ている結 果について述べる。試料表面の微細構造と発光スペクト ルの関係を研究した結果, いろいろとおもしろい現象が 見つかっている。第4 章はまとめである。

\section{2. $\mathbf{S T M}$ 発光}

STM 発光分析が探針直下のローカルな物性評価手法 として期待できることを述べたが，その物性はSTM発 光の強度, 偏光特性, スペクトルなどに反映される。以 下に述べるようにこれらの計測から表面物性の違った側 面が観測されている。

\section{1 発光強度}

ここでの発光強度とは, 検出器が感度を有する波長域 にわたって積分した強度を指す。STM の発光実験はバ イアス電圧 (試料-探針間電圧) が数 V, トンネル電流が 数 $\mathrm{nA}$ から数十 $\mathrm{nA}$ でなされるのが一般的であるが，こ れは数十 $\mathrm{nW}$ の電力に相当する。この電力がすべて可視 光に変換されたとしても毎秒 $10^{9}$ 個程度の光子数にしか ならない。実際には光子への変換効率はせいぜい $10^{-4}$ 程度であるし, 光検出系の効率も数 \% 程度である。し たがって，STMからの発光強度は光子数計測法 (フォト ンカウンティング法)を用いてもせいぜい数千 cps（毎秒 当たりのカウント数)である。この発光を分光して計測 しょうとするとさらに光検出器に入る光量は減少するの で, その計測には信号蓄積のためのより長い時間が必要 になる。一方，STM の探針ドリフトはきわめて特殊な 場合4)をのぞき不可避であろうから, 発光計測時間はで きるだけ短くしたい。 
以上のような背景から発光計測時に分光器を使うこと なくSTM発光を直接光検出器に導き, その強度のみを 計測することがよく行われている。光検出器としては光 電子増倍管を用いるのが一般的である。光電子増倍管が 感度を有する波長域は陰極面の材料や (光電子増倍管の) 空の材質による。たとえば，石英空をもつ光電子増倍管 では波長 200nm から 7 800nm 程度の広い波長域に感 度を有するものもあるが, 空材が嗍珪酸ガラスであれば 計測可能な最短波長は $300 \mathrm{~nm}$ ぐらいとなる5)。

$\mathrm{Ag}$ 蒸着膜を試料としたSTM発光において, 以上のよ うにして計測されたSTM 発光強度が nm オーダーの探 針移動で変化することが報告されている6)。これは発光 強度計測により $\mathrm{nm}$ オーダーの試料の物性が識別可能と なることを示しているが，どのような物性を反映したも のであるかは材料や計測条件に依存するので注意して議 論する必要がある。

可視から近紫外域にプラズモンの周波数を有する $\mathrm{Au}$, $\mathrm{Ag}, \mathrm{Cu}$ のような貴金属を試料とした場合には(トンネル 電子により励起された) 探針直下の試料の表面に局在し た電子の集団運動 (ローカル・プラズモン) からの発光 が主であると考えられており, 発光強度の変化をもたら すものは試料表面幾何形状 (ローカル・プラズモンのモー ドに影響を与える) や試料表面の電子状態 (ローカルプラ ズモンの励起確率に影響を与える) が考えられている7)。

金属以外では GaAs(100) 面上に成長させた $\mathrm{p}$ 型 GaAs$\mathrm{AlGaAs}$ 超格子を超高真空中で䢃開し，その断面のSTM 発光強度を計測した例がある ${ }^{8)}$ 。発光は $\mathrm{GaAs}$ 井戸層で 起こり，探針が GaAs 層上にあるときとAlGaAs 層上に あるときで発光強度に差がでる。すなわち, 試料表面の STM発光強度マッピングを描くと, GaAs 層とAlAs 層 を識別することができる。このときの位置分解能はnm オーダーであると報告されている。GaAs/AlGaAs 境界 と探針 (トンネル電子が注入されている場所)の間の面 内方向の距離の関数として発光強度の変化を計測するこ とにより, 少数キャリアー(今の場合電子) の輸送パラ メーターも評価されている9。

$\mathrm{GaAs}$ のの STM 発光強度変化を計測した例では, ナノメーターサイズの機械的なダメージを受けた GaAs 表面からの STM 発光光強度は (ダメージがない場合に 比較して) 著しく弱くなることが報告されている ${ }^{10)} 。$

ポーラスシリコンを試料として表面凹凸と STM発光 強度との関係を調べた事例も報告されている11。表面の ナノメーター・オーダーのサイズの凹凸に相関して発光 強度も変化することを見出している。このことはポーラ スシリコンからのSTM発光がナノメーター・サイズの シリコン微結晶での量子閉じこめ効果の結果起こってい
ると考えれば理解できるが，この仮定をさらに確認する ためには個々の表面微細構造からの発光スペクトルを計 測する必要がある。すなわち量子閉じこめの結果発光が 起こるのであれば，発光スペクトルにサイズ効果が見ら れるはずである12)。

\section{2 偏光特性}

STM 発光の偏光特性の計測からスピン偏極電子トン ネルに関する情報が得られている13)。探針に磁化した $\mathrm{Ni}$ ，試料に高ドープの p 型 $\mathrm{GaAs}(110)$ の組合せで STM 発光の右向き円偏光強度と左向き円偏光強度を計測し, その結果からトンネル電子のスピン偏極率を評価してい る。この発光は $\mathrm{Cs}$ と $\mathrm{O}_{2}$ を適量共吸着させた負の電子親 和力をもつ $\mathrm{GaAs}$ からの光電子が円偏问入射光によりス ピン偏極するよく知られたプロセス ${ }^{14)} の$ 逆過程に相当す るものである。また, 試料の磁気特性がSTM発光の偏 光特性に反映されることも報告されている15)。

一般に光の電界べクトルの向き(偏光)を計測すると その発光源 (電気双極子) の空間的な方向をある程度決 めることができる。光が波数べクトル $\boldsymbol{k}$, 電界ベクトル $\boldsymbol{E}$ をつ直線偏光した光であったとすると，放射源の電 気双極子 $\boldsymbol{p}$ は $\boldsymbol{k} \times \boldsymbol{E}$ 方向に平行な成分をもつことはな い。同じことであるが，電気双極子 $\boldsymbol{p}$ からの双極子放射 光は $\boldsymbol{p} \times \boldsymbol{k}$ に平行な電界ベクトルをもつことはない。

潮田はSi 単結晶からのSTM発光の偏光特性を計測し た ${ }^{3)}$ 。Si 単結晶からの STM 発光は, Si-MOS 接合から の発光の機構の研究結果 ${ }^{15)}$ からの類推から, トンネル電 子からの直接発光であると考えられる。トンネル電子は 主に試料表面に垂直に流れるであろうから(トンネル電 子の試料表面に平行な運動量成分 $\sim 0$ ), 発光源となる双 極子もやはり試料表面に垂直に生成されると考えるのが 自然である。

実際，Si(100) 面からの発光の偏光特性は（期待した ように) 試料表面に垂直に立った双極子から期待される ものであった。しかし Si(111) 面からのSTM 発光では 試料面に平行な成分をもつ双極子もトンネル電子により 生成されている。なぜ試料面方位によってこのようにト ンネル電子により生成される双極子の向きが異なるのか 理解されていない。

\section{3 スペクトル}

STM 発光に関して 2 種類のスペクトルが観測されて いる。一つはアイソクロマート・スペクトルと呼ばれる もので, 探針-試料間のバイアス電圧の関数として発光 強度を計測したものであり，基本的にはトンネル電子に よる逆光電子分光スペクトルと考えることができる。も う一つは通常の発光分光と同じように分光器を用いて計 測される発光のスペクトルである。 
アイソクロマート・スペクトルは最初シリコン単結晶 を試料として通常の逆光電子分光で用いられる光子工ネ ルギー $9.8 \mathrm{eV}$ 近辺に感度を有するガイガーミュラー管を 光検出器としてなされた(6)。シリコンの逆光電子分光ス ペクトルと比較すると, 対応する構造に加えて, STM 発光に特有な構造として探針一試料間の電界放出領域 (電子のもつ運動量が実数となる領域)における共鳴に 基づくものが観測されている。

またアイソクロマート・スペクトルは発光機構を理解 するための手がかりの・つとしてよく用いられる。この ときには“何ボルトのバイアス電圧で, 興味ある波長域 の発光が強くなった，弱くなった”ということが重要で あるので, $9.8 \mathrm{eV}$ 以外の適切な周波数領域で計測がなさ れる ${ }^{17)}$ 。

発光スペクトル計測は，2.1で述べたように，発光強 度計測よりもより注意深い計測が必要になるが，そこか ら得られる情報は単なる発光強度よりも豊富になる。 STM 発光スペクトルの計測は計測の容易さから近紫外 から近赤外の間でもっぱらなされている。近紫外よりも 短波長になると, 集光光学素子や分光器にいろいろな制 約が発生し，高效率発光計測が困難になる。また，近赤 外よりも長波長域になると陰極材料の制約から光電子増 倍管を使うことができなくなる。各種半導体受光素子の 性能も最近格段によくなってきているようであるが, STM の発光のように時間的にランダムにやってくる微 弱光計測にはまだ光電子増倍管と光子数計測法の組合せ がすぐれているように思う。

発光スペクトルを観測することにより GaAs や CdS の ような直接遷移型の半導体ではバンド間遷移で発光が起

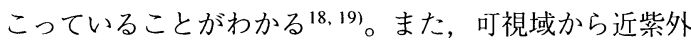
域にプラズモンの振動数を有する $\mathrm{Au}, \mathrm{Ag}, \mathrm{Cu}$ などの貴 金属では材料のプラズモン振動数から期待される波長領 域で発光が起こっていることがわかる20)。

これまでバイアス電压の関数として STM 発光スペク トルを測定した結果はしばしば報告されているが，試料 位置を变化させて発光スペクトルを計測し，表面微細構 造と発光スペクトルを関係づけて検討することにより試 料表面物性を研究することはなされていなかった。最近 われわれのグループではこのような計測を開始した。そ の結果いろいろ興味深い現象が観測されている。次章で はそのうちのいくつかを紹介する。

\section{STM 発光スペクトルの表面微細構造 依存性}

\section{1 金微粒子の STM 発光スペクトル}

従来より，真空蒸着法により作製された比較的大きな
表面凹凸を有する貴金属試料のSTM発光スペクトル中 にはバイアス電圧に依存しない特徴的な構造が見られる ことが報告されている6)。しかしこのような構造は阁じ材 料の単結晶を試料としたSTM発光では観測されない20)。 このことから，このスペクトル中の構造は探針-試料間 に形成されたローカル・プラズモンの特性を反映したも のであると予想されているが，表面凹ら構造と発光スペ クトル構造の関係 (相関) は計測されていなかった。

伊藤らは金蒸着試料について発光スペクトルと表面凹 凸の相関を最近計測した21)。試料は真空蒸着法でカバー ガラス、上に作製した金薄膜（厚さ〜 $50 \mathrm{~nm}$ ) であり，探針 はPtIrである。STM 像計測および発光実験は真空中で なされた。なお，発光計測系を含む実験装置の詳細は文 献2)に示されている。

図 1 (a)に定電流モードで測定した $200 \mathrm{~nm} \times 200 \mathrm{~nm}$ の STM像を示す。この像から $40 \mathrm{~nm}$ 程度のサイズの金微粒 子が形成されていることがわかる。このうちの任意の... つの微粒子について 1 4 ら発光スペクトルを計測した。このときのバイアス電圧 は $2.5 \mathrm{~V}$ (このとき, 電子は探針から試料に向かってトン ネルしている)，トンネル電流は5nAである。金のSTM 発光は, $\mathrm{d}$ バンド吸収の影響により, $2 \mathrm{eV}$ 以上の光子工 ネルギー領域ではあまり発光しない。したがってバイア

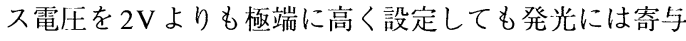
しない。また発光強度はトンネル電流に比例して増大す るので発光計測の観点からはトンネル電流が高いほうが 有利であるが，あまり高いと試料表面の微細構造を破壊 する。以上のようなことを考虑してバイアス電圧，トン ネル電流を設定した。実験結果を図 1 (b) に示す。

探針が金の微粒-子の頂上近辺 (図 1(a)中 1 の位置) に あるときの発光スペクトルは $1.6 \mathrm{eV}$ と $2.0 \mathrm{eV}$ の光子工ネ ルギー近傍に:つの構造 $\mathrm{A}, \mathrm{B}$ をち， $\mathrm{A}$ の構造のほう がBのそれよりも強い。探針を微粒子の周辺部に向かっ て 2, 3, 4 と移動していくと, A, B二つの構造のエネル ギー位置は変化せず，お互いの強度関係のみが変化する ようにスペクトルが変化している。

伊藤らは $1.6 \mathrm{eV}$ と $2.0 \mathrm{eV}$ の構造はプラズモンのダイ ポール・モードとマルチポール・モード23ににそれぞれ対 応していると考えると図 1 (b) のような変化が理解でき ることを指摘している。すなわち金微粒子の凸部上に探 針があるときにはダイポール・モードが強く励起される ので1.6eVの構造が強調されたスペクトルになる。探針 が凹部にあるときには (対称性から) ダイポール・モー ドは励起されないのでマルチポール・モードの $2.0 \mathrm{eV} の$ 構造が強調される。

もし以上のようなことが起こっているとすると探針が 


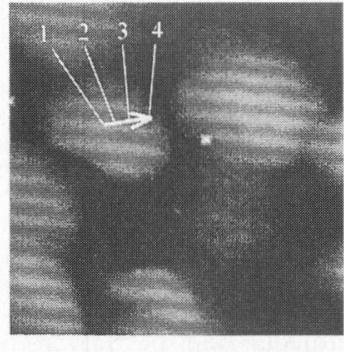

(a)

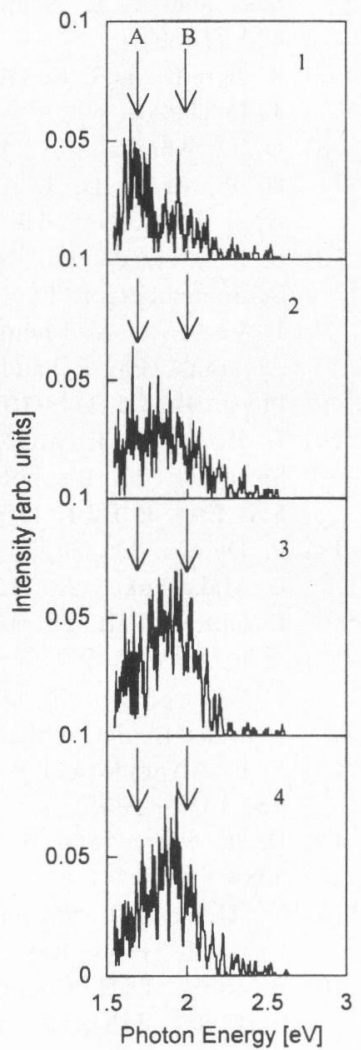

(b)

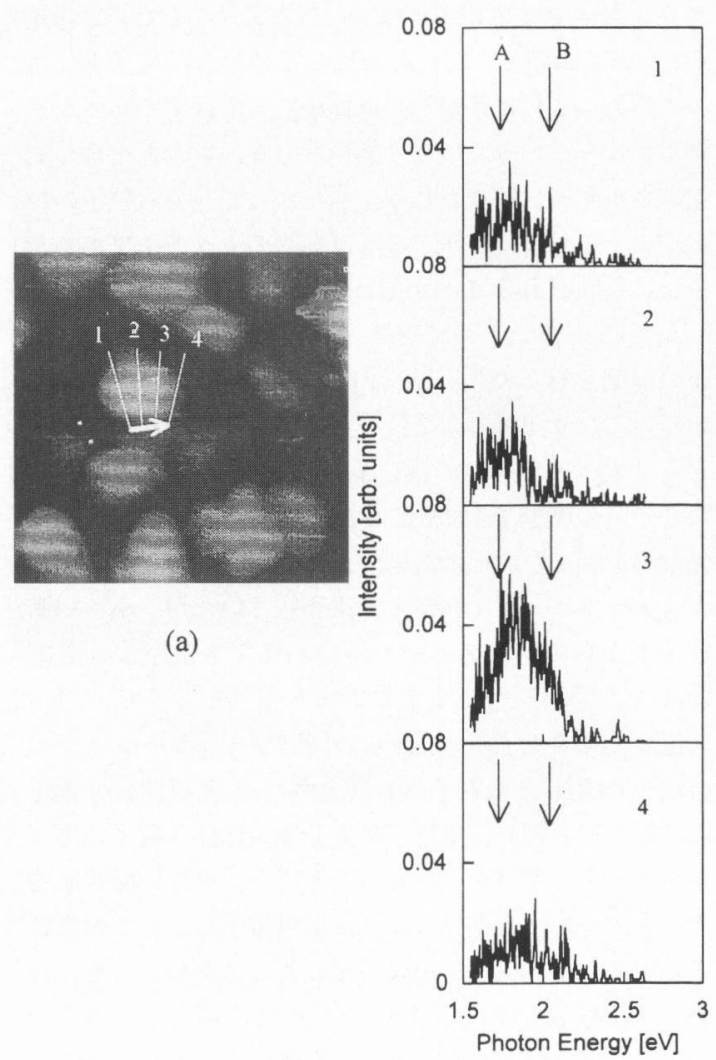

(b)

図 1 (a) 金蒸着膜の定電流モードで計測したSTM 像

(b) STM 像中 1 4 4で示した各位置に探針を移動したとき の発光スペクトル

微粒子と微粒子の境界を移動するときには発光スペクト ルの変化は生じないと予想される。実際 図 2 に示すよ うに，定電流モードで測定した $200 \mathrm{~nm} \times 200 \mathrm{~nm}$ の STM 像中, 探針が微粒子と微粒子の境界を移動するとき, 発 光強度は探針位置により多少変化するが, スペクトル形 状自体は (図 1 と比較したらよくわかるように) 変化し ていない。

\section{2 酸化膜上の金微粒子からの STM 発光 スペクトル}

容量 $C$ のコンデンサーに素電荷 $e$ をえたときの充電 エネルギーはよく知られているように，

$$
\Delta E=\frac{1}{2} \frac{e^{2}}{C}
$$

で与えられる。Cが小さくなるに従って充電エネルギー は大きくなる。Cが $1 \times 10^{-19} \mathrm{~F}$ 程度まで小さくなると， この充電エネルギーは $1 \mathrm{eV}$ 程度の大きさをもつようにな り, その効果 (単電子によるチャージアップ効果) は無 視できなくなる24)。このような効果に起因する現象で最

図 2 (a) 定電流モードで計測した金蒸着膜のSTM 像

(b) STM 像中 1 4 4で示した各位置に探針を移動したと きの発光スペクトル

近しばしば話題にのぼるのがクーロン階段である。たと えば，薄いアルミニウム酸化膜の上に少量金を蒸着した 系では金は直径 $10 \mathrm{~nm}$ 程度の微粒子を形成し，この微粒 子上にSTM探針を移動をしてI-V 特性を計測すると階 段状の特性が観測されることが報告されている25)。これ は基板アルミニウムー酸化膜-金微粒子，および金微粒 子-真空ギャップ-探針で構成される二つの直列につな がった容量の小さいコンデンサーの単電子チャージアッ プに起因すると考えられている。

この薄い酸化膜上に作製した金微粒子を試料として STM 発光を行うことは以下に述べるような理由でたい へん興味がある。金属を試料とする STM発光ではトン ネルした電子が金属試料でもちうる最大の過剩エネル ギー (金属試料の中でこの電子がもつエネルギーとフェ ルミエネルギーの差) が発光のカットオフを決める。試 料が非常に大きな静電容量をもつ単結晶金属のような場 合，探針-試料間のバイアス電圧を $V_{0}$ とすると，試料の 光学特性的な理由により発光が阻害されない限り, 発光 
のカットオフエネルギーは $e V_{0}$ となる(ここで $e$ は素電 荷)。いま問題にしている金微粒子の場合，電子トンネ ルの結果，この電子が対向電極中で得るはずであった過 剩エネルギーのうち -部は無視できない大きさをもつ充 電エネルギーに費やされる。したがって，金微粒子の単 電子チャージアップが起これば発光のカットオフエネル ギーに反映されることが期待される。

実際に上述のような試料について室温で発光スペクト ルの計測を行った ${ }^{26)}$ 。試料のSTM 像を計測した結果, いろいろなサイズの金微粒子が形成されていることがわ かり，大きいサイズの微粒子 (面積 $S=490 \mathrm{~nm}^{2}$ ) と小さ いサイズの微粒子 (面積 $S=32 \mathrm{~nm}^{2}$ ) に探針を移動して発 光計測を行った。その結果，大きい微粒子からの発光の カットオフはバイアス電圧で決まっていたが，小さい微 粒子上からの発光スペクトルはバイアス電庄よりも約 77meVだけ低いカットオフエネルギーをもっていた。

温度効果を含むAmman らの回路シミュレーションの 方法 ${ }^{27)}$ で探針-金微粒子および金微粒子一基板間に分割さ れる電圧を評価し，単電子のトンネルに伴う発光のカッ トオフエネルギーを見積もったところ，小さい微粒子の カットオフエネルギーのシフトは単電子によるこの微粒 子のチャージアップに起因していることがわかった。た いへん興味深いのは (クーロン階段の場合と異なり) チャージアップが発光に及ほす影響は室温でも観測でき ることである。

\section{4. ま と め}

第 2 章ではSTM 発光を特徵づける「強度, 偏光特性, スペクトル」という観点からこれまでSTM 発光に関し て報告されてきたことを眺めてみた。第3章ではわれわ れの最近の研究結果について紹介した。なお，STM 発 光スペクトルの角度依存性も面的いテーマであるが281紙 面の関係で省略した。また，STM 発光の理論面に関す る研究もなされているが，これについても完全に割愛さ せていただいた。

\section{文献}

1) J. K. Gimzewski : SPIE 1009, 274 (1988).

2) D. L. Abraham, A. Veider, Ch. Scoenenberger, H. P. Meier, D. J. Arent and S. F. Alvarado : Appl. Phys. Lett. 56, 1564 (1990).

3) S. Ushioda : Solid State Commun. 84, 173 (1992).

4) D. M. Eigler and E. K. Schweizer : Nature 344, 524 (1990).

5) 浜松フォトニクス 光電子増倍管カタログ.

6) J. H. Coombs, J. K. Gimzewski, B. Reihl, J. K.
Sass and R. R. Schutter : J. Microscopy 152 425 (1988).

7) R. Berndt and J. K. Gimzewsk : Phys. Rev. B $4 \mathbf{8}$, 4746 (1993).

8) D. L. Abraham, A. Veider, Ch. Shoenenberger, H. P. Meier, D. J. Arent and S. F. Alvarado : Appl. Phys. Lett. 56, 1564 (1990).

9) S. F. Alvarado, Ph. Renaud, D. L. Abraham, Ch. Schroenenberger, D. J. Arent and H. P. Meier : J. Vac. Sci. \& Technol. B9, 409 (1991), S. F. Alvarado, Ph. Renaud and H. P. Meier : J. de Phys. III, C6-271 (1991).

10) J. Horn, R. Richter, H. L. Hartnagel, C. A. Sprossler, M. Bischoff and H. Pagnia : Mater. Sci. Eng. B B20, 183 (1993).

11) P. Dumas, M. Gu, C. Syrykh, J. K. Gimzewski, I. Makarenko, A. Halimaoui and F. Salvan : Europhys. Lett. 23, 197 (1993).

12) 最近われわれのグループではこのような計測を 行った:K. Ito, S. Ohyama, Y. Uehara and S. Ushioda (to be published).

13) S. F. Alvarado and P. Renaud : Phys. Rev. Lett. 68, 1387 (1992).

14) D. T. Pierce and F. Meier : Phys. Rev. B15, 5484 (1976).

15) Y. Uehara, J. Watanabe, S. Fujikawa and S. Ushioda : Phys. Rev. B (in press).

16) B. Reihl, J. H. Coombs and J. K. Gimzewski : Surf. Sci. 211/212 156 (1989).

17) I. I. Smolyaninov, M. S. Khaikin and V. S. Edelman : Phys. Lett. A 149, 410 (1990), R. Berndt and J. K. Gimzewski, Ann. Phys. (Germany) 2, 133 (1993).

18) R. Berndt, R. R. Schlitter and J. K. Gimzewski : AIP Conf. Proc. 241, 328 (1991).

19) R. Berndt and J. K. Gimzewski : Phys. Rev. B45, 14095 (1992).

20) R. Berndt and J. Gimzewski : Phys. Rev. Lett. 30, 3796 (1991).

21) K. Ito, S. Ohyama, Y. Uehara and S. Ushioda : Surf. Sci. (in press).

22）上原洋 一, 潮丒資勝：応用物理 60, 1235 (1991).

23) H. Reather : Surface Plasmons on Smooth and Rough Surfaces and on Gartings (Springer Tracts in Modern Physics 111, Springer-Verlag, Berlin 1988).

24) J. Lambe and R. C. Jaklevic : Phys. Rev. Lett. 22, 1371 (1969).

25) A. Amman, S. B. Field and R. C. Jaklevic : Phys. Rev. B48, 12104 (1993).

26) Y. Uehara, S. Ohyama, K. Ito and S. Ushioda : submitted to Phys. Rev. Lett.

27) M. Amman, R. Wilkins, E. Ben-Jacob, P. H. Maker and R. C. Jaclevic : Phys. Rev. B43, 1146 (1991).

28) S. Ushioda, Y. Uehara, M. Kuwahara : Appl. Surf. Sci. 60/61, 448 (1992). 